\title{
Enhancing postgraduate learning and development: a participatory action learning and action research approach through conferences
}

\section{Introduction \\ Conference presentation and subsequent publication in scientific journals and books can be difficult or uncomfortable experiences for postgraduate students. Yet publicly disseminating their work, orally and in writing, is vital if their research is to have any influence on policy or practice. Indeed, it can be vital for the learning and development of postgraduates, as emergent researchers, to gain positive experience through all opportunities that conferences can offer - to become part of a learning and research community, share one's own and others' research and ideas, learn from and with others, network, develop possibilities for collaboration and publication, and generally progress towards a well-developed identity as a researcher.}

As supervisors of postgraduate students leading action learning and action research projects, we aim to develop their ability to practise action learning and critically reflect on their own learning needs, and to conduct rigorous and authentic action research. We are action researchers, so we believe in and advocate the transformational potential (Author $1,2010)$ of research: for research to have value, it must not only generate knowledge on a theoretical level, but also have practical and emancipatory outcomes. As researchers and research participants collaborate to generate theory and address mutually identified concerns, outcomes should include not just discernible improvement in the quality of their lives, but also epistemological and ontological shifts that lead to sustainable change in how they live and in their capacity to respond to future challenges. In other words, as postgraduate supervisors, we see ourselves as being in the business of developing lifelong learners who strive to embody the values and principles of participatory action learning and action research (PALAR) in their professional and personal lives.

We therefore adopt a capability approach to our postgraduate supervision. Developing people's capability, according to Sen (1999), enables them to broaden what they recognise as their choices about how they wish to be and what they wish to do. Developing postgraduate students' capability through PALAR as our preferred genre of action research helps to ensure that their research experience is not only a means to an end for themselves through attaining a degree and developing holistically through coming to understand that their learning and research can have a lasting and beneficial impact on their own lives. It also enables them to help develop the capability of people participating in their research projects. We want the students we supervise to go back to their respective spheres of influence and be able to cascade their learning as they interact with others, in their professional or personal capacities. We want the supervision process to help students expand their capacity to make both meaningful life choices and contributions to knowledge and sustainable community wellbeing. That's why we need to ensure that we create space for them to grow and develop as people and as professionals 
beyond the narrow aim of graduation. We believe the most efficacious way to do so is through the principles and practices of PALAR.

We recognise conferences to be a valuable and mostly under-appreciated space for this growth and development, personally and professionally, through PALAR. Yet we have found, and literature confirms (Haley, Wiesner and Robinson 2009; Nel and de Beer 2004), that most conferences do not present an optimal learning and development environment for postgraduates as emerging researchers. Postgraduate students tend to be overawed by 'expert' researchers (who often simply present their students' work), making these students too nervous to engage in deep learning as they wait anxiously for their turn to present, 'to get it over and done with'. Allocated time for presentations, questioning and other aspects of conference also works against students maximising learning opportunities. Most conferences allow only 20 minutes for a presentation, with three to four consecutive presentations and only ten minutes for questioning of all presenters at the end, which works against balanced discussion time for each paper. Student presenters waiting to be questioned are often preoccupied with anxiety about what audience members may ask them, which also diminishes their chance to learn through the discussions.

Recognising the valuable learning and development opportunities through conferences that postgraduates may be unable to use or maximise, we designed and facilitated a structured support program to help students turn any conference into what we call here a learning conference. The learning conference, conceptualised initially by Ravn (2007), is a conference where scheduling deliberately builds in time for active interaction, engagement and reflection between and among delegates, rather than one-sided presentations with a few questions from the audience at the end. Whereas Ravn (2007) explains what a learning conference is, (and Authors 3 \& 2, 2011 further develop this concept and its utility), in this paper we are concerned with the place of postgraduates in a learning conference. We explore how postgraduates can use and help create opportunities most effectively so that conferences are truly spaces for their rich learning and professional development - through PALAR.

Here we share how we put into practice the principles of PALAR to foster the development of capability in postgraduate students through conferences. Our approach offers them structured support to prepare for, fully participate in, and reflect on, the experience of attending a conference to maximise its potential as a learning conference. We begin by explaining the theoretical paradigm of PALAR that underpins our supervisory actions and the approaches we promote among our students, and then explain the methods we used to generate and analyse the data we discuss. We then explain how we conceptualised and put these methods into practice for the workshops, presenting a brief overview of the structured support program we designed for students' pre- and postconference learning, before discussing the themes that emerged in response to our research question: "How does a participatory action learning and action research approach to the preparation of postgraduate students for a conference influence their learning and development during the conference and beyond?". We conclude with 
PALAR is thus more than just a methodology. It is a paradigm that transforms and continually informs people's ontological, axiological and epistemological understanding of themselves and the world.

In terms of postgraduate supervision, we see that the capability theory of Sen (1999), which links human development, quality of life and freedom (Walker 2005), aligns with the principles and processes of PALAR, which work towards helping people to: i) determine what is best for them in line with their values, and ii) draw on the resources and input of a supportive group to develop the knowledge and skills to be able to pursue their goals. We do not supervise only to develop competence in research methodology and reporting, but rather with a view to developing the postgraduate student holistically, so that they emerge from the supervisory process with a clearer understanding of self, others and the systems that influence their lives. By modelling the 7Cs and 3Rs in our interaction with students, and helping students to embed these into their respective projects, we hope to facilitate gradual and sustainable growth on cognitive, emotional, social and spiritual levels so students are better able to set and attain goals they believe will add value to their lives and indirectly to the lives of others. Fletcher (2015, pp.68-69) 
explains how PALAR embodies the principles of neuroscience that sees learning as a process that is not only cognitive, but also dependent on social and emotional factors. Thus our approach to group supervision is to create a positive and supportive learning ecology that minimises barriers to learning and opens all participants to full participation and engagement. This approach is confirmed and explained in detail by Author 2 (2014) who concludes:

The importance of group support in boosting students' morale, self-confidence and learning has not drawn the attention it deserves as a means of reducing high attrition and low or late completion rates among postgraduate students. Through participating in collaborative supervisor-candidate sets and contributing to the workshop program, supervisors can create a more co-operative and open environment for learning and research that is appropriate for the purpose of action research, with intellectual enrichment for supervisor as well as student. (p. 741)

\section{Overview of structured support workshop program and method of evaluation}

Our combined expertise lies in action research and action learning, publication and supervision, as well as academic support for postgraduate students and academic staff members. We designed and facilitated a support program as a workshop for postgraduates to maximise their understanding and experience of and contribution to a 'learning conference culture' (Authors 2015, pp.173-188). We were assisted in the preconference workshop by an academic writing practitioner.

The participants of the structured learning conference program were six PhD and five MEd students who had all been working together in a larger PALAR community engagement project supported by a South African National Research Foundation (NRF) grant, eight of them for the last three years and three for at least one year. Each student had a specific project of their own within this PALAR project, and they had all been meeting monthly as an action learning set to share their learning with each other. Almost all were working fulltime in education. Three were full-time university academics, two were aspiring to attain employment as academics, one held an administrative post at a university, one was a Human Resource Manager at a college, three were practising school teachers, and one was a full-time student. All were proficient in spoken English, but only one considered English as her mother-tongue; the others were native speakers of Afrikaans or setSwana'. The first author of this article was supervisor of all bar two of the students. Those two were supervised by other colleagues who collaborated with her on the NRF community engagement project, so she had interacted with both of them closely in the learning set over the duration of the project. All bar one student, who had enrolled in the previous year, had attended at least one postgraduate workshop with the third author. The second author was not known to the students before the workshop, but feedback indicated that they quickly felt at home with her.

All the students were attending the World Congress of ALARA (Action Learning and Action Research Association) in Pretoria (4-7 November 2015) in the week following the pre- 
conference workshop. All were presenting a paper. The workshop's aim as a support program was thus to enable participants to develop the competence and confidence to engage fully in the learning experience afforded by the conference and to benefit from opportunities the World Congress presented as a space for rich learning and development, especially since it had been designed expressly as a learning conference. We wanted to help these students to be able to use PALAR principles to identify their learning and how they can apply it to enhance their future studies, publication of their work and their respective career trajectories, alongside the contributions of their learning/research to broader community development. Table 2 outlines the support program's activities and their purposes. Although we had developed a rough outline for both of these workshops (pre- and post-conference), at the start of each we negotiated with the participants around their learning needs to prioritise certain activities over others. Similarly, at the end of each day we read their written reflections and adjusted the program as we thought helpful or necessary. The post-conference workshop was based on our learning about the students' needs, based on their reflections.

\section{PLEASE INSERT TABLE 2 HERE}

Table 2: Activities and aims of pre- and post-conference workshops

We positioned the pre- and post-conference sessions as action learning set meetings with the following stated aims:

In this informal and interactive workshop we come together as an action learning set, particularly to work on participants' academic writing needs. Our approach is hands-on ... revising written samples, editing, questioning, thinking aloud and on paper, suggesting, discussing and any other activities that inspire our learning. So please bring your ideas, questions, and wonderings to enrich your and our learning experiences (Preamble to program invitation).

We did this in keeping with and as demonstration of PALAR principles: to indicate we recognise student participants as fellow learners with us, to try to even out the power differentials inherent in our relationships, and show that we value their inputs to enhance the learning of all present. We were aware that some students might perceive us as 'expert' practitioners and researchers, and so might not feel as comfortable contributing as they would in their usual supervisory groups. We wanted to create 'a spirit of mutuality between teachers and students as joint inquirers' (Merriam, Caffarella and Baumgartner 2012, p. 85), in line with our PALAR commitment to valuing the input and participation of all. We endeavoured to keep the atmosphere as mutually supportive and friendly as possible, while still encouraging deep engagement with the work.

We generated data through written and oral reflections by both students and facilitators on each of the pre-and post-conference workshops and through student written reflections on each day of the conference. We individually analysed this data for themes that would help us to answer our research question, before we shared our analyses with each other to reach consensus on the final themes. This helped to increase the 
trustworthiness of the findings, as did sharing the final discussion with the participants for their validation (Creswell 2005). Students signed consent forms, allowing us to use their feedback for research purposes. The larger NRF project had already received ethical clearance from the university in question.

\section{How does PALAR enhance postgraduate learning and development?}

Two themes emerged from our analysis of the participants' written and oral reflections to help answer our research question: "How does a participatory action learning and action research approach to the preparation of postgraduate students for a conference influence their learning and development during the conference and beyond?"

The two themes are:

1. The focus on relationship-enhanced learning; and

2. Preparation for conference, which enabled the postgraduate students to maximise their learning experience during and beyond the conference

We discuss each theme in relation to verbatim quotations from the data, as well as in relation to relevant literature, and our theoretical frameworks. The participants are identified as researchers by (Rn).

\section{Theme 1: The focus on relationship enhanced learning}

All participants mentioned, either pre- or post-conference, that they perceived the learning climate of the workshops as positive:

I appreciated the relaxed atmosphere that prevailed at the session (R2)

It was a day well spent - thank you! Thank you for caring and showing and living out your values of sharing (R8)

Being able to voice my insecurities in a safe and nurturing space was invaluable (R7)

Participants valued inputs from their fellow students as much as from facilitators.

The fact that we know each other helped and over lunch we could 'feed off' other inputs and new understandings (R6)

The pre-conference workshops, refining our power point presentations, getting feedback and having group discussions all contributed to establishing a sense of trust and belonging before the congress (R10).

Others mentioned the feelings of comradeship in the group (R7); the encouragement from the learning set (R4); and how 'the pleasant academic space created an atmosphere of Gemütlichkeit [cordiality, friendliness]' (R10). However, cultural differences were also at work. One student felt that 'respect for elders, which is part of my culture' (R8) 
hampered her engagement, in that she was too timid to say what she felt at one point, and she spent so much time worrying about her inability to voice her true opinion that she missed out on some of the discussion and learning. This alerted us to the need to check how each person in the group is feeling, rather than assuming the majority voice speaks for all participants. At a later supervision session with the student, the supervisor was able to discuss this response and help her understand how emotions can hamper or enhance learning, and how she could devise strategies to cope with this in future in her own life and in her practice as a teacher. The importance of individual critical reflection was once again highlighted, as we would not have realised that one student was struggling within the larger group of positive participants unless we had read the reflections immediately after the workshop.

Deepening of peer relationships at the pre-conference workshop seemed to increase the students' desire to support each other at the Congress, as many of them mentioned the help from others before, during and after their presentations in terms of technical assistance, moral support and gentle constructive coaching. It is well documented in the literature that a positive learning climate not only deepens emotional engagement in the particular learning experience, but also leads to a positive attitude towards collaboration, which in turn leads to more lasting success in life outside the classroom (Hoffman 2009; Ukpokodu 2010). Self-esteem, belief in self-efficacy and interpersonal skills are all more easily fostered in such a collaborative climate, leading to the probability that learners will seek rather than avoid learning later in life, thus becoming the lifelong learners necessary in our fast changing, diverse and turbulent world (Author 2 2012). In a PALAR process, fostering positive, caring relationships is paramount for ongoing growth and development of people involved, yet supervision by means of such dialogical groups is still relatively uncommon in South African higher education, at least until recently. All students in this study were familiar with hierarchical, one-to-one relationships that postgraduate students generally have with their 'Profs' and valued and appreciated this more dialogical approach since it helped them to feel that their input was valuable. The PALAR experience in supervision had offered them the support they needed to feel competent, not only at a technical level, but as emerging academic researchers.

I am still positive about doing action research and Prof has been an absolute amazing role model for me to learn from. She is now helping me to write my first article and she is guiding me through the painful sharpening of becoming an academic, without making me feel unimportant (R3).

I have started to trust myself enough to demonstrate my research findings with emotional videos knowing that it may solicit questions of ethics. However, I am now confident enough to answer them irrespective of who is in the audience so there has been growth and development. I also had a look at the video clips captured where I am presenting at all three conferences and it appears that I am more relaxed in Pretoria than anywhere else and I see this as another indicator of the excellent work Prof is doing in developing her students not just in thesis work but in making public their findings (R6). 
Recognition of successful contributions and learning outcomes is also a key principle of PALAR (Authors 2015). Since this group comprised mainly people who had been socialised within a divisive and unjust Apartheid society whose legacy continues today, learning to respect and communicate as equals with people from different linguistic, cultural, race, religious and economic backgrounds is especially valuable for future personal and professional interaction (Author 1 2014). In addition to enhancing supportive peer relationships, participants especially appreciated the facilitators' individual coaching sessions:

It was only at the conference that I truly realised the value of the coaching that we received before the conference. (R4).

Coaching from $\mathrm{Z}$ at the pre-conference session has put me on my PhD journey (R9)

Mentoring sessions and practical advice from $Y$ was great, as well as her personal examples of how to overcome crises (R5).

One-to-one coaching allowed individual students to talk about specific aspects of their studies and lives that they needed help with, and they valued it as an alternative to the group sessions. It not only helped them personally, but also gave them insight into how they can work effectively with participants in their research projects in future, so all can have a more 'humanising experience' (R6) through their participation in the project. They also mentioned that the specialised focus of each coach was useful - one for helping with improving presentations, one for language/writing issues and one for a more general coaching session on personal and project-related issues.

The evidence presented in this theme adds weight to the claim that the affective-sociocognitive approach of PALAR (Fletcher 2015, pp. 67-68) that we embodied in our design of and interaction within this program contributed to improving student capabilities as both academic and social beings. Critical reflection on the pre- and post-workshop process and on their role within it helped them to realise the value of developing supportive relationships and being open to learning from all experiences. The supportive relationships helped to increase their commitment towards the group to make a 'success' of the conference; and the respectful, synergistic communication helped them to recognise their peers' strengths and resources, which they shared freely to support each other during the conference.

Theme 2: Preparation for the conference enabled them to maximise the learning experience

Our aim in the pre-conference workshop in particular was to build confidence, and ultimately competence, of these postgraduate students in presenting and discussing their research at an international forum. Although their learning expectations at both pre- and post-conference workshops were very 'technical' (e.g., how to construct a sentence; 
abstract composition; 'dos and don'ts' of presentation), their reflections revealed that they learnt much more than how to produce a good PowerPoint presentation:

Another good day. A large majority of the presenters I listened to said that they were new to action research and probably couldn't answer difficult questions. They added that they would like to ask questions of the experts in the audience. While I understand their fears, I think that a conference is an opportunity to share your personal experiences without fear of not being "enough". Not knowing enough or having done enough action research that's nonsense. We are all here to learn. Even sharing challenges and failures is valid data for others to consider and react to. The success of my own study was aided by avoiding the pitfalls highlighted by the other members of our action learning set (R8).

This student seems to have grasped the value of a conference to deepen learning, and the experience of being part of a PALAR group has taught her that "not knowing" is not something to be ashamed of but rather a place from which to start or further develop learning; the point is to learn at every opportunity. PALAR highlights recognition of different kinds of knowledge and ability. The questions that stem from such knowledge, and understanding of why those particular questions were asked, are seen to be as valuable to collective learning as the answers provided. Learning in the PALAR sense derives from coaching and asking 'fresh questions' (Revans 1991), and not from direct instruction or provision of what are presented as definitive answers. Coaching implies that everyone has potential to learn and act to contribute to knowledge creation and learning; they just need help in unearthing such potential. As R4 testified: 'It was at the conference that I truly realised the value of the coaching that we received before the conference. The calibre of support was highlighted by the central role our facilitators played in the conference.' This participant also learnt 'not to be intimidated by academic talk' and said the group critique enabled him to be more open and to listen to the input of others. Other participants (R6, R3, R9 and R10) voiced similar learning.

Postgraduate students in South Africa face many challenges, some similar to students in the rest of the world and some related to the persisting destructive legacy of Apartheid under-education (Pupwe 2015). The Christian Nationalist education curriculum of the Apartheid era actively discouraged critical thinking. It was based on a rigid racial ideology that through inferior education opportunities disadvantaged Black students - and, by implication, the communities in which they lived (Bozalek and Boughey 2012). This curriculum still has lasting negative impact on perceptions of students' ability - by students themselves, and within the Higher Education system in general. As one participant in our program indicated:

When we arrived at the conference centre I felt a bit nervous because I did not know what was actually expected of me. What made my condition worse was when I saw that the conference was dominated by Whites because when we 
grew up we were told that "lekgowa ke sehlare sa Mosotho" figuratively meaning that "White people know everything" (R10).

Many postgraduate students have to study in a second or even third language, as was the case with members of this group. They are often mature students who are not familiar with current qualitative research approaches, and in many cases their undergraduate or Masters degree was not sufficiently rigorous to prepare them for postgraduate study (Cloete, Mouton and Sheppard 2015).

However, the pre-conference preparation seemed to help debunk such myths and to help students recognise the intrinsic value of their own input. In using PALAR principles, the pre-conference sessions helped to 'set the tone for the conference' (R4), and enabled participants to embrace learning at the conference and to enter the space prepared to share: 'As an academic I felt valued and I could share my learning in this space' (R3).

After the conference, critical reflection on their role and learning during the conference enabled them to deepen their knowledge about themselves as researchers, how to network, and how to make the best of academic learning experiences.

What I did learn about my own research and that of my colleagues in the NRF project is that if we thought we had problems, we should see what some others had experienced. I really felt for them as they presented. When I reflect on how I had empathy for them it was reaffirming my own ontology of caring that I have for the voiceless, suffering fellow colleagues. I will always stand with and for the marginalised, oppressed, the down trodden as that is my position from the time of engaging in liberation theology. When I heard of the plight across the world of those who suffer, I can be so glad that we have a methodology that can bring about healing and contribute to a more just world (R6).

Being an action researcher is an internal and ongoing process and I must never underestimate the power of learning experiences (R3).

Participant 4 said he went from thinking 'I am a novice researcher ... and I will never be good' to 'I will learn more, I will get better, I just have to never stop trying' (R4). They also learnt how to deal with tension in the group, how to be humble and not expect everything to be $100 \%(\mathrm{R} 1)$; that they should be more process-oriented and recognise the journey to be more important than the destination (R10); to view their work as valuable (R7); and to take control of their research journey, rather than feel a victim of circumstances (R5).

These reflections reveal that workshop participants' learning went deeper than just presenting a paper confidently at this conference. Participants learnt that they have the ability to stand their ground within an academic environment and have the freedom to control their own research trajectories. This understanding of freedom is a fundamental concept in the capability approach (Orton 2011) and it develops when people recognise they can make choices to remove social and structural barriers to goal attainment 
(Burchardt 2004). Participants in this study - all of them postgraduate students - were able to overcome feelings of academic inferiority because the pre-conference workshops and the PALAR experience in supervision had offered them the support they needed to feel competent, not only at a technical level, but also as emerging academic researchers:

Networking during the conference will help me to gain new knowledge from other scholars that will contribute to my study (R11).

I can feel proud about my own knowledge I have and how I am applying it. Competency only improves when we commit to practise the work and not be afraid to make mistakes (R4).

The development is perhaps best summed up by the gradual increase in confidence of the participant (R10) quoted above who came to the workshop thinking her knowledge was inferior to that of 'White people', as indicated by some excerpts from her reflections on the conference:

[the book launch] was the most inspiring moment hence I even gate crashed to take photos with ALARA members. I began to visualise myself launching my own book one day, with so many people from different countries across the globe. I did not sleep that night, cracking my head about the title for my first article ...

During the plenary session I was fascinated by the reflections made by ALARA members. I began to realise that this journey needs passion and commitment to one's work. During the discussions, I wanted to talk but still feeling inferior, so I thought people would devalue my contribution ...

During the reflection session, I was happy and motivated hence I also stood up during the Skype connection and spoke my mind.

Participants thus seemed to develop as participatory action learners and action researchers as they felt more competent, were better able to critically reflect, and to communicate with and learn from others. They were able to compromise their expectations and be open to coaching, as well as begin to coach and support others.

\section{Critical reflection on our own learning}

Critical reflection on the participants' data discussed above has highlighted some important lessons that we can use to improve our practice as supervisors and coaches of postgraduate students. We realise that working in a collaborative team with a mix of personalities and expertise enabled us to give individual attention to students on specific areas. Students also had more choice of who to go to for coaching, enabling them to approach the person they felt they would most like to learn from. Individual coaching was highly valued by all participants, particularly those who perceived themselves as being less competent, therefore in future we will ensure that we build in more time for this coaching. We intended to do this during the conference, but both we and the students became so involved in other activities that our 'coaching' intentions did not materialise. 
Reflecting on the post-conference data, we learn that it is important to schedule the post-conference workshop as soon after the conference as possible - even the next day. For logistical reasons, we could not arrange this second workshop for two months, and then only about half of the students could attend. In our case, this was not such a disaster since the lead author has an ongoing supervisory relationship with each student and could follow up in "normal" group supervision sessions to support the students in writing up their conference papers for possible publication. However, those who did not participate post-conference missed out on the varied input as explained above. Another advantage of adding a day to the main conference for a post-conference workshop would have been to give we three authors the opportunity for face-to-face discussion, critical reflection and meta-reflection, which are always more effective and deeper in person than by email correspondence later.

\section{Conclusion}

In this article, our aim has been to share how to foster the development of capability in postgraduate students through structured support, to prepare for and reflect on the experience of attending a learning conference. We wanted to provide evidence of how a PALAR approach to supervision, which has a broader and more holistic focus on learning and development than traditional degree-oriented methods, can help postgraduate students to develop capabilities that will enhance their daily lives on both professional and personal levels. We presented evidence that suggested participants in the pre- and post-conference workshops we facilitated for our support program had replaced their feelings of inferiority, intimidation and incompetence with perceptions of their value as people and as researchers who have something worthwhile to contribute, and can so do competently. Of course, this transformation did not come about only as a result of this one support program. The PALAR supervision group had evolved over a period of almost three years for most of the students, and this program was thus a culmination of their learning and development. However, the structured pre- and post-conference workshops did support them to make this learning public, to move with confidence out of the safe space of the PALAR group into an international research arena. The collaboration and support from their peers during the conference enabled them to cement their improved self-perceptions, which in turn enabled them to be open to more learning.

We have explained how action learning as an intricate component of postgraduate supervision can help even the most timid and self-denigrating students to rethink themselves as competent and confident researchers. This gives us in turn the boldness to suggest that a PALAR approach to postgraduate learning and development can better prepare professionals who have not only the skills and know-how to do their jobs, but also the capabilities to make decisions that will enhance not only their own lives, but also the lives of those within their spheres of influence. We end with an excerpt from the post-conference reflections of a workshop participant who had previously expressed feelings of inferiority due to her race: 
I am so glad we have the contacts of all people who attended the conference because where I hit the rock, I will communicate with the relevant people. I want to thank my promoter for allowing me to explore my potential in a World Congress because through it I have developed faith and self-confidence and I don't even perceive myself as a novice researcher anymore. I feel like I have a lot of experience to share with people (R10).

For us, this level of transformation deepens our conviction that (1) action learning has to be at the heart of all learning and development; (2) group postgraduate supervision using PALAR fosters relationship-building, trust, a supportive environment, collaboration, communication and so forth (see Table 1); and (3) conferences can be made into learning conferences through a support program consisting of pre- and post-conference workshops using PALAR principles, as demonstrated in this article, to make them a space for maximising postgraduate learning and development.

\section{Acknowledgements}

The research that this article was based on was funded by the National Research Foundation (NRF). The opinions and findings expressed therein are those of the authors and the NRF cannot take responsibility for them.

We would also like to acknowledge the postgraduate students in the NRF project who participated in the two workshops we discuss here. We are especially grateful to Maureen Todhunter for co-facilitating the pre-conference workshop with us to provide language tuition.

\section{References}

Author 1. 2014

Author 1. 2010.

Authors, 2015.

Author 2. 2014.

Author, 2. 2013.

Author 2. 2012.

Author 2. 2011.

Author 3, 2. 2011.

Bozalek, V., and C. Boughey. 2012. "(Mis)framing Higher Education in South Africa." Social Policy \& Administration 46:688-703. doi:10.1111/j.1467-9515.2012.00863.x 
Brydon-Miller, M., and P. Maguire. 2009. "Participatory action research: Contributions to the development of practitioner inquiry in education." Educational Action Research 17(1): 79-93.

Burchardt, T. 2004. "Capabilities and disability: the capabilities framework and the social model of disability." Disability and Society 19: 735-51.

Cloete, N., J. Mouton, and C. Sheppard. 2015. Doctoral education in South Africa: policy, discourse and data. Cape Town: African Minds.

Creswell, J. 2005. Educational Research: Planning, Conducting and Evaluating Qualitative and Quantitative Research. NJ, Upper Saddle River: Merrill/Pearson Education.

Fals Borda, O., ed. 1998. People's participation: Challenges ahead. Bogota: Tercer Mundo Editores.

Fletcher, M. 2015. "Professional learning." In Professional learning in higher education and communities: Towards a new vision for action research, edited by 0 . Zuber-Skerritt, M. Fletcher \& J. Kearney, 41-75. London: Palgrave Macmillan.

Haley, K. J., C.A. Wiesner, and E.E. Robinson. 2009. "Encountering new information and perspectives: Constructing knowledge in conference contexts." The Journal of Continuing Higher Education 57: 72-82.

Hoffman, D. M. 2009. "Reflecting on social emotional learning: A critical perspective on trends in the United States." Review of Educational Research 79: 533-556.

Merriam, S.B., R.S. Caffarella, and L.M. Baumgartner. 2012. Learning in adulthood: $A$ comprehensive guide. John Wiley \& Sons.

Nel, J., and K.J. De Beer. 2004. "Selling higher education to the highest bidder: Corporatising learning." Interdisciplinary Journal 3(2): 157-165.

Orton, M. 2011. "Flourishing lives: the capabilities approach as a framework for new thinking about employment, work and welfare in the 21st century." Work, Employment \& Society 25: 352-360.

Pupwe, O.K. 2015. "Three Essays on Racial Wage Differentials in South Africa." Unpublished Phd diss., University of Western Michigan, USA.

Ravn, I. 2007. "The learning conference." Journal of European Industrial Training 31(3): 212-222.

Reason, P., and H. Bradbury, eds. 2013. The Sage handbook of action research: Participatory inquiry and practice 3rd ed. London: Sage.

Revans, R. 1991. Action learning: Reg Revans in Australia [Video series produced by Ortrun Zuber-Skerritt (now on DVD)]. Brisbane: Video Vision, University of Queensland. 
Sen, A. 1999. Development as Freedom. New York: Alfred A. Knopf.

Ukpokodu, O. N. 2010. "How a sustainable campus-wide diversity curriculum fosters academic success." Multicultural Education 17: 27-36.

Walker, M. 2005. "Amartya Sen's capability approach and education." Educational Action Research 13: 103-110.

\footnotetext{
i setSwana is one of the 11 official languages of South Africa and is spoken by approximately 3.6 million people in South Africa.
} 


\begin{tabular}{|c|c|}
\hline $\begin{array}{l}\text { The } 7 \text { Cs of PALAR for } \\
\text { character building }\end{array}$ & Characteristics and principles of PALAR \\
\hline Communication & $\begin{array}{l}\text { Communication is dialogical, symmetrical and respectful } \\
\text { rather than directive and one-sided }\end{array}$ \\
\hline Commitment & $\begin{array}{l}\text { Commitment to the process achieves the negotiated } \\
\text { programme outcomes as well as participants' own learning } \\
\text { and development goals and contributes to the learning and } \\
\text { development of others in the group }\end{array}$ \\
\hline Competence & $\begin{array}{l}\text { Competence is gained for self-directed learning through } \\
\text { recognition of learning needs and setting of own personal } \\
\text { learning goals }\end{array}$ \\
\hline Compromise & $\begin{array}{l}\text { Participants must be flexible and able to compromise } \\
\text { personal standpoints in order to enable progress towards } \\
\text { negotiated mutual outcomes }\end{array}$ \\
\hline Critical reflection & $\begin{array}{l}\text { On-going critical reflection must be facilitated at all stages } \\
\text { of the process with self-reflection being the starting point }\end{array}$ \\
\hline Collaboration & $\begin{array}{l}\text { Collaboration means active participation by all in a } \\
\text { democratic decision-making process throughout }\end{array}$ \\
\hline Coaching & $\begin{array}{l}\text { Learning is shared, not only between facilitators and } \\
\text { participants, but also among participants as all give freely } \\
\text { of their insights and experience for the benefit of others }\end{array}$ \\
\hline 3 Rs & $\begin{array}{l}\text { The above characteristics of PALAR are operationalized as } \\
\text { follows: }\end{array}$ \\
\hline Reflection & $\begin{array}{l}\text { Reflection must be continual, iterative, critical and self- } \\
\text { critical in a collaborative, supportive learning environment }\end{array}$ \\
\hline Relationship & $\begin{array}{l}\text { Development of democratic, authentic, supportive and } \\
\text { committed relationships leads to participants' ability to } \\
\text { communicate in a respectful way and to reach compromise } \\
\text { when needed }\end{array}$ \\
\hline Recognition & $\begin{array}{l}\text { Recognition and reward encourage growth and } \\
\text { development of participants' increasing competence as } \\
\text { researchers, practitioners, professionals and human beings }\end{array}$ \\
\hline
\end{tabular}

Table 1: The 7Cs and 3Rs of PALAR 
Table 2: Activities and aims of pre- and post-conference workshops

\begin{tabular}{|c|c|}
\hline \multicolumn{2}{|c|}{ Day 1 - Pre-conference (two days) } \\
\hline Item on programme & Learning objective \\
\hline $\begin{array}{l}\text { - Introductions } \\
\text { - Participants' expectations and needs } \\
\text { - Relationship building }\end{array}$ & $\begin{array}{l}\text { To list all the expectations in order } \\
\text { to adapt the proposed programme } \\
\text { as needed. } \\
\text { To create trust for effective } \\
\text { collaboration and communication }\end{array}$ \\
\hline $\begin{array}{l}\text { Action writing and editing } \\
\text { - Useful tips for clear, coherent academic writing } \\
\text { - Useful tips on academic editing (of own and } \\
\text { others' work) }\end{array}$ & $\begin{array}{l}\text { To sensitize participants about } \\
\text { appropriate styles and tone osf } \\
\text { academic writing. }\end{array}$ \\
\hline $\begin{array}{l}\text { Academic writing } \\
\text { - Frameworks for presenting oral/written papers } \\
\text { - Difference between research and writing } \\
\text { - Quality criteria } \\
\text { - The quality of an action research thesis/article } \\
\text { - Structured abstract }\end{array}$ & $\begin{array}{l}\text { To teach concise writing and getting } \\
\text { to the essence of the matter. } \\
\text { To emphasise what makes a quality } \\
\text { (AR) thesis } \\
\text { To structure an abstract. } \\
\end{array}$ \\
\hline $\begin{array}{l}\text { Review and discussion of the Learning } \\
\text { Conference article to illustrate the PIP process }\end{array}$ & $\begin{array}{l}\text { To explain a new publication genre } \\
\text { To prepare participants for making } \\
\text { the most of the 'learning } \\
\text { conference' }\end{array}$ \\
\hline $\begin{array}{l}\text { Academic publishing } \\
\text { - Choosing publisher/journal } \\
\text { - Becoming familiar with the journal's approach, } \\
\text { language, style, etc. } \\
\text { - Getting feedback from 'critical friends' } \\
\text { - Following guidelines for authors }\end{array}$ & $\begin{array}{l}\text { To allow participants to practise } \\
\text { critical reflection and to share it with } \\
\text { others } \\
\text { To create space for cooperative } \\
\text { learning } \\
\text { To understand journal requirements }\end{array}$ \\
\hline $\begin{array}{l}\text { - Reflection Diary structure } \\
\text { - Reflections (individual and as a group), } \\
\text { discussion and planning tomorrow's agenda }\end{array}$ & $\begin{array}{l}\text { To teach participants how to keep a } \\
\text { reflective diary that they can revisit } \\
\text { and use as one source of data } \\
\text { amongst others }\end{array}$ \\
\hline \multicolumn{2}{|c|}{ Day 2 - Preconference } \\
\hline $\begin{array}{l}\text { Reflections } \\
\text { - Individual and group reflections on Day } 1 \text {, } \\
\text { following the structure of the Reflection Diary } \\
\text { - Any new issues? }\end{array}$ & $\begin{array}{l}\text { To "debrief" participants and } \\
\text { provide opportunity to add items to } \\
\text { the programme in a non-threatening } \\
\text { environment. }\end{array}$ \\
\hline Discussion of participants' submitted abstracts and & To polish participants' presentations \\
\hline
\end{tabular}

\begin{tabular}{|c|c|}
\hline & \\
\hline Item on programme & Learning objective \\
\hline $\begin{array}{l}\text { Coaching } \\
\text { - Discussion of participants' needs/queries as } \\
\text { they rotate across the three facilitators: } \\
\text { (academic perspective), (language, writing, } \\
\text { editing perspective) and (specific South African } \\
\text { context for publishing in higher education, rules, } \\
\text { regulations, suggestions and oral presentations). }\end{array}$ & $\begin{array}{l}\text { To give participants an individual } \\
\text { opportunity to voice their fears and } \\
\text { insecurities and to ask any questions } \\
\text { they might have } \\
\text { To share our expertise, experience } \\
\text { and advice as critical friends }\end{array}$ \\
\hline \multicolumn{2}{|l|}{ Post conference (one day) } \\
\hline $\begin{array}{l}\text { - Catching up and sharing the three 'Most } \\
\text { Important Points' (MIPs) from the conference } \\
\text { experience in terms of learning outcomes } \\
\text { - Participants' expectations and needs }\end{array}$ & $\begin{array}{l}\text { To re-align the group after a two } \\
\text { month absence. } \\
\text { To allow them an opportunity to } \\
\text { voice their needs. }\end{array}$ \\
\hline $\begin{array}{l}\text { From first to final draft } \\
\text { - Difference between first and final drafts } \\
\text { Explaining the technical "must-haves" } \\
\text { - Logical flow } \\
\text { - Typical errors } \\
\text { - Critical reader } \\
\text { - Writing the main message to the reader in } 25 \\
\text { - Mords } \\
\text { - Mind mapping }\end{array}$ & $\begin{array}{l}\text { To practice the skills of focusing on } \\
\text { essential contents and arguments } \\
\text { before writing full drafts and } \\
\text { considering details, language and } \\
\text { style }\end{array}$ \\
\hline $\begin{array}{l}\text { Writing an integrated literature review } \\
\text { - How to organise notes from reading } \\
\text { - A ten step plan to write a literature review } \\
\text { - The use of a bibliographic data base, e.g. } \\
\text { Endnote }\end{array}$ & $\begin{array}{l}\text { To assist them to take relevant notes } \\
\text { from sources; to organise the notes } \\
\text { in a system and coherent argument; } \\
\text { to use logical connectors to } \\
\text { structure the literature review. }\end{array}$ \\
\hline Coachin & $\begin{array}{l}\text { to } \\
\text { er. }\end{array}$ \\
\hline $\begin{array}{l}\text { Editing own work for integrity } \\
\text { - Sharing an editing matrix to ensure consistency } \\
\text { across chapters }\end{array}$ & $\begin{array}{l}\text { To emphasise the importance of } \\
\text { editing, explaining terminology and } \\
\text { creating a structure. }\end{array}$ \\
\hline $\begin{array}{l}\text { Reflection on the coaching of the workshop } \\
\text { Sharing our learning from the coaching (common } \\
\text { mistakes, specific issues, huge improvements) }\end{array}$ & $\begin{array}{l}\text { To build their confidence that we all } \\
\text { make mistakes, but we should work } \\
\text { on improving our work. }\end{array}$ \\
\hline $\begin{array}{l}\text { Evaluation and closure } \\
\text { Reflection on learning an }\end{array}$ & $\begin{array}{l}\text { To encourage them to reflect deeply } \\
\text { about all aspects of the learning } \\
\text { journey and to continue to do so }\end{array}$ \\
\hline
\end{tabular}


